\title{
Nutrient and Antioxidant Properties of Value Added King Chilli (Capsicum chinense) Products
}

\author{
Aparna Kuna ${ }^{1}$, Manas Ranjan Sahoo², M. Sowmya ${ }^{1 *}$, Premi Devi Mayengbam², \\ M. Dasgupta ${ }^{2}$, M. Sreedhar ${ }^{1}$ and Shinglai Tholemfhuang ${ }^{1}$
}

\author{
${ }^{1}$ MFPI - Quality Control Laboratory, PJTS Agricultural University, Rajendranagar, \\ Hyderabad, Telangana, India \\ ${ }^{2}$ Division of Horticulture, ICAR Research Complex for NEH Region, Imphal, Manipur, India
}

*Corresponding author

\begin{tabular}{|l|}
\hline Ke y w o r d s \\
King chilli, \\
Processing, Value \\
addition, Nutrient and \\
Antioxidant properties \\
\hline Article Info \\
\hline $\begin{array}{l}\text { Accepted: } \\
\text { 02 May 2018 } \\
\text { Available Online: } \\
\text { 10 June 2018 }\end{array}$ \\
\hline
\end{tabular}

\section{A B S T R A C T}

The objective of the present study was to assess the nutrient and antioxidant properties of fresh, primary and secondary processed King chilli (Capsicum chinense) products. Six secondary products (King chilli sauce with pulp and extract, king chilli toffee, curry paste, fish masala powder and sprinkler masala powder) were developed by incorporating varying amounts of King chilli. Antioxidant and bioactive components were estimated using standard methods in triplicates and were subjected to sensory evaluation studies. Fibre content in fresh and processed products of King chilli ranged from $0.36 \%$ to $8.90 \%$. Higher fat content $(3.30 \%)$ was found in dry King chilli. Protein content ranged from $0.12 \%$ to $10.27 \%$. Reducing sugar values ranged from $1.26 \mathrm{mg} / \mathrm{g}$ to $2.11 \mathrm{mg} / \mathrm{g}$. Highest TSS content $(3.67 \mathrm{mg} / \mathrm{g})$ was found in fish masala powder and the least $(0.69 \mathrm{mg} / \mathrm{g})$ was found in fresh King chilli. Highest ascorbate content was found in fresh King chilli as compared to the primary and secondary processed products. Capsaicin content was highest $(7.65 \%)$ in fresh King chilli. Proline content in King chilli and its products ranged from 5.02 to $104.28 \mu \mathrm{mol} / \mathrm{g}$. DPPH scavenging activity $(36.86 \%)$ and reducing power $(0.55 \mathrm{abs})$ was highest in dry King chilli. Total flavonoid content was found to be highest (22.49 $\mathrm{mg} / \mathrm{g}$ ) in dry King chilli. Total phenolic content ranged from 20.61 to $410.76 \mathrm{mg} / \mathrm{g}$ of PE). Highest carotenoid content $(3.99 \mathrm{mg} / \mathrm{g}$ ) was observed in dry King chilli. Statistical analysis showed that the total phenolic content in different King chilli products was strongly correlated $(\mathrm{p}>0.005)$ with scavenging DPPH $(\mathrm{r}=0.95)$, reducing power $(\mathrm{r}=0.95)$ and total flavonoid content $(r=0.86)$. In the vision of modern era, processed foods are earning distinction and gaining higher preference globally among the consumers. This study shows that processed King chilli products have health beneficial bioactive compounds and its value added products could have a high demand in the global market if processing of King chilli is taken up in a big way.

\section{Introduction}

King chilli belongs to the genus Capsicum and species chinense, which is world famous for its heat content. King chilli measures 60 to $85 \mathrm{~mm}$ (2.4 to 3.3 inches) long and 25 to $30 \mathrm{~mm}$ (1.0 to 1.2 inches) wide with a red, yellow, orange, or chocolate color. The plant 
came into limelight when it was announced as the hottest chilli in the world in $2006^{1}$. The people of the North-eastern India use the fruits of King chilli in different food formulations like flavouring curries due to its high-quality fragrance and pungency and also for various medicinal treatments like rheumatism, arthritis, gastritis, ankylosing spondylitis, digestive diseases ${ }^{2}$ and to reduce chronic congestion $^{3}$. It is also used as a bird, animal and insect repellent as well as a biochemical pesticide. The extremely hot or burning sensation of chilli is due to the presence of capsaicinoids found only in Capsicum ${ }^{4}$.

In northeastern India, King chilli has been cultivated in a traditional manner since time immemorial and there exists a considerable amount of genetic variability among the landraces ${ }^{3}$. The pharmaceutical applications of capsaicinoids are attributed to their analgesic, antiarthritic, anticancer and antioxidant properties. In fact, capsaicin has been at the centre of intense research for elucidating the basis of its pharmacological properties and exploiting the therapeutic potential ${ }^{5}$. It has also been reported that capsaicin inhibits the growth of prostate cancer cells ${ }^{6}$. The antioxidative capacity of chilli is higher than ginger, garlic, mint and onion ${ }^{7}$, which may play an important role in the process of chemoprevention ${ }^{8}$.

In the vision of the modern era, processed foods are earning distinction and gaining higher preference globally among the consumers. However, a systematic study on the health beneficial bioactive compounds of these underutilized plant species has not been documented even though there is a high demand for phytoceuticals in the global market. Hence, the present work was conducted to develop and standardize few value added King chilli products and estimate the nutrient and antioxidant property in fresh, dried and processed products to observe the differences in nutrient composition on processing.

\section{Material and Methods}

Fresh and dried mature King chillies were procured from the local market at Imphal, Manipur. Other raw materials were procured from the local markets of Hyderabad. Fresh King chilli (deseeded), was blanched in hot water at $90 \pm 2{ }^{\circ} \mathrm{C}$ for $2 \mathrm{~min}$ with the ratio of king chilli to water of 1:7. The blanched king chillies were then immediately cooled in cold water at $4^{\circ} \mathrm{C}$. The king chillies were then dried to remove the residual water and were ground to pulp, which was used in product development. The dried kind chillies were dried again at $50^{\circ} \mathrm{C}$ for $2 \mathrm{~h}$ in a pre-heated $\left(50^{\circ} \mathrm{C}\right)$ tray drier. The dried king chilli sample was ground to fine powder using a grinder (Waring Commercial Blender, WCG75, Torrington, CT) at a medium speed for $2 \mathrm{~min}$. The powder was then sieved using a sieve analyzer (Retsch, AS200 basic, Hann, Germany). The powder with particle size in the range of $150-430 \mu \mathrm{m}$ was vacuum packed in an HDPE package until further analysis.

King chilli sauce with pulp/extract, King chilli curry paste, King chilli toffee, King chilli sprinkle masala powder/fish masala powder were done with pulp and powdered King Chilli in various quantities and the products were standardized. The standardized products were evaluated for nutrient and antioxidant properties. Nutrient composition (crude fat, protein, fiber, Total Soluble Solids - TSS and Reducing sugars - RS) of King chilli and its products were performed using Association of Official Analytical Chemists (AOAC, 2000) methods. Ascorbate, Capsaicin and Proline content of King chilli and its products were done by standardized methods as described by Mukherjee and Choudhuri (1983), Quagliotti (1971) and Bates et al., (1973) respectively. Antioxidant activity of King chilli and its 
products were done by various methods - Free radical scavenging activity (DPPH Assay) by Blois (1958), Total flavonoids by Ordonez et al., (2006), Total phenolic content using Folin-Ciocalteu method (Lowry, 1951), Reducing power by the method of Oyaizu (1986), Total Carotenoids by Jensen (1978).

\section{Statistical analysis}

To determine the statistical significance of antioxidant activity, ANOVA technique was used. Pearson's bivariate correlation test was used to calculate correlation coefficient between the contents of total phenolics and flavonoids, carotenoids, proline, scavenging activity and reducing power. Means and Standard deviations were calculated for results of nutrient analysis. All values were expressed as mean \pm standard deviation of three parallel measurements (Snedecor and Cochran, 1969).

\section{Results and Discussion}

The results of nutrient estimation of fresh, primary and secondary processed King chilli products are summarized in Table 1. Highest fat content $(3.30 \pm 1.07 \%)$ was found in dry King chilli as compared to the fresh King chilli $(1.79 \pm 0.28)$. On the other hand, much lower fat content $(0.82 \pm 0.03 \%)$ was reported by Ananthan et al., (2014) in Naga King chilli which may be due to variation in agro-climatic variation and season as reported by Sanatombi et al., (2008). Fibre content was lowest in King chilli sauce with extract $(0.36 \pm 0.25 \%)$ and highest in dry King chilli $(8.90 \pm 0.50 \%)$. Protein content in fresh and dry King chilli was found to be $3.63 \pm 1.16 \%$ and $4.46 \pm 0.72 \%$ respectively. Reducing sugar value was found to be highest in dry King chilli $(2.11 \pm 0.07 \mathrm{mg} / \mathrm{g})$ as compared with the fresh King chilli and all the secondary processed products. Reducing sugar content of fresh King chilli, King chilli curry paste and King chilli sprinkle masala powder was not statistically significant ( $p>0.05)$. Study on two varieties of fresh green chilli (Capsicum annuum L) by Take et al., (2012) observed a reducing sugar content of $2.8 \%$ and $3.6 \%$ respectively. Highest TSS content $(3.67 \pm 0.02$ $\mathrm{mg} / \mathrm{g}$ ) was found in fish masala powder and the least $(0.69 \pm 0.02 \mathrm{mg} / \mathrm{g})$ was found in fresh King chilli.

The results of ascorbate, capsaicin and proline content of King chilli and its products are given in Table 2. Content of ascorbate in fresh, dry and secondary processed products ranged from $0.57 \pm 0.03 \%$ to $1.13 \pm 0.41 \%$.

A study on Capsicum annuum L. by Ji-Sun et al., (2011), reported ascorbic acid content of $1.74 \pm 1.87 \%$ and $1.98 \pm 19.64 \%$ in green and red paprika which relates to our findings of $1.13 \pm 0.41 \%$ in fresh King chilli. Increase in ascorbate content in few secondary processed products could be due to the addition of ascorbate rich ingredients like lemon juice, tomatoes, tamarind, cloves and coriander seeds during processing. Capsaicin content was found to be highest $(7.65 \pm 2.93 \%)$ in fresh King chilli which is similar to the findings of $7.35 \%$ by Ananthan et al., (2015) in Capsicum chinense Jacq. On the other hand, very low capsaicin contents of $5.38 \mathrm{mg} / \mathrm{g}, 2.36 \mathrm{mg} / \mathrm{g}$ and $10.48 \mathrm{mg} / \mathrm{g}$ in dry matter weight of pericarp, seed and placenta respectively was reported by Jana et al., (2014) in Capsicum annuum L. However, the capsaicin content significantly decreased in all the secondary processed products which could be due to reduced content of King chilli in product as compared to other ingredients.

Proline content in King chilli and its products ranged from 5.02 to $104.28 \mu \mathrm{mol} / \mathrm{g}$. Higher proline content was observed in primary and secondary processed products as compared to the fresh King chilli. 
Int.J.Curr.Microbiol.App.Sci (2018) 7(6): 1-8

Table.1 Nutrient composition of King chilli and its products

\begin{tabular}{|l|c|c|c|c|c|}
\multicolumn{1}{|c|}{ TREATMENTS } & \multicolumn{1}{|c|}{$\begin{array}{c}\text { Crude fat } \\
(\%)\end{array}$} & $\begin{array}{c}\text { Fibre } \\
(\%)\end{array}$ & $\begin{array}{c}\text { Protein } \\
(\%)\end{array}$ & $\begin{array}{c}\text { TSS } \\
(\%)\end{array}$ & $\begin{array}{c}\text { RS } \\
(\%)\end{array}$ \\
\hline Fresh King chilli & $1.79^{\mathrm{b}} \pm 0.28$ & $4.63^{\mathrm{b}} \pm 0.47$ & $3.63^{\mathrm{e}} \pm 1.16$ & $0.69^{\mathrm{e}} \pm 0.02$ & $1.26^{\mathrm{d}} \pm 0.06$ \\
\hline Dry king chilli & $3.30^{\mathrm{b}} \pm 1.07$ & $8.90^{\mathrm{a}} \pm 0.50$ & $4.46^{\mathrm{d}} \pm 0.72$ & $1.91^{\mathrm{d}} \pm 0.11$ & $2.11^{\mathrm{a}} \pm 0.07$ \\
\hline $\begin{array}{l}\text { King chili sauce with } \\
\text { pulp }\end{array}$ & $0.52^{\mathrm{c}} \pm 0.17$ & $0.93^{\mathrm{d}} \pm 0.15$ & $0.37^{\mathrm{f}} \pm 0.14$ & $3.22^{\mathrm{b}} \pm 0.26$ & $1.71^{\mathrm{b}} \pm 0.03$ \\
\hline $\begin{array}{l}\text { King chili sauce with } \\
\text { extract }\end{array}$ & $0.60^{\mathrm{b}} \pm 0.18$ & $0.36^{\mathrm{e}} \pm 0.25$ & $0.42^{\mathrm{f}} \pm 0.08$ & $3.11^{\mathrm{c}} \pm 0.12$ & $1.62^{\mathrm{c}} \pm 0.04$ \\
\hline Fish Masala power & $6.72^{\mathrm{a}} \pm 4.26$ & $1.03^{\mathrm{d}} \pm 0.15$ & $9.61^{\mathrm{b}} \pm 0.20$ & $3.67^{\mathrm{a}} \pm 0.02$ & $1.75^{\mathrm{b}} \pm 0.02$ \\
\hline $\begin{array}{l}\text { King chilli Sprinkle } \\
\text { masala powder }\end{array}$ & $2.46^{\mathrm{b}} \pm 0.46$ & $1.16^{\mathrm{d}} \pm 0.20$ & $10.27^{\mathrm{a}} \pm 0.96$ & $3.32^{\mathrm{b}} \pm 0.02$ & $1.37^{\mathrm{d}} \pm 0.05$ \\
\hline King chilli toffee & $2.75 \pm^{\mathrm{b}} 0.08$ & $0.46^{\mathrm{e}} \pm 0.31$ & $0.12^{\mathrm{f}} \pm 0.52$ & $3.47^{\mathrm{a}} \pm 0.02$ & $1.65^{\mathrm{c}} \pm 0.05$ \\
\hline King chilli curry paste & $9.15^{\mathrm{a}} \pm 0.23$ & $2.70^{\mathrm{c}} \pm 0.79$ & $6.71^{\mathrm{c}} \pm 6.00$ & $3.01^{\mathrm{c}} \pm 0.05$ & $1.29^{\mathrm{d}} \pm 0.05$ \\
\hline
\end{tabular}

All values are represented as Mean \pm SD at 5\% significant level. Mean values with similar superscripts within a column do not differ significantly $(\mathrm{P}>0.05)$.

Table.2 Ascorbate, capsaicin and proline content of King chilli and its products

\begin{tabular}{|l|c|c|c|}
\hline \multicolumn{1}{|c|}{ TREATMINTS } & $\begin{array}{c}\text { ASCORBATE } \\
(\mathrm{mg} / \mathrm{g})\end{array}$ & $\begin{array}{c}\text { CAPSAICIN } \\
(\%)\end{array}$ & $\begin{array}{c}\text { PROLINE } \\
(\mu \mathrm{mol} / \mathrm{g})\end{array}$ \\
\hline Fresh King chilli & $11.39^{\mathrm{a}} \pm 0.41$ & $3.39^{\mathrm{b}} \pm 1.12$ & $5.02^{\mathrm{g}} \pm 0.15$ \\
\hline Dry king chilli & $6.26^{\mathrm{e}} \pm 0.75$ & $7.65^{\mathrm{a}} \pm 2.93$ & $75.82^{\mathrm{b}} \pm 4.33$ \\
\hline King chili sauce with pulp & $6.13^{\mathrm{e}} \pm 0.75$ & $0.15^{\mathrm{c}} \pm 0.24$ & $9.85^{\mathrm{f}} \pm 0.19$ \\
\hline King chili sauce with & $5.76^{\mathrm{f}} \pm 0.03$ & $0.14^{\mathrm{c}} \pm 0.14$ & $20.55^{\mathrm{e}} \pm 0.96$ \\
\hline extract & $9.77^{\mathrm{b}} \pm 0.08$ & $0.15^{\mathrm{c}} \pm 0.05$ & $36.81^{\mathrm{c}} \pm 0.14$ \\
\hline Fish Masala power & $6.65^{\mathrm{e}} \pm 0.15$ & $0.08^{\mathrm{c}} \pm 0.06$ & $36.16^{\mathrm{c}} \pm 0.25$ \\
\hline King chilli Sprinkle & & & \\
\hline masala powder & $8.23^{\mathrm{c}} \pm 0.28$ & $0.28^{\mathrm{c}} \pm 0.12$ & $104.28^{\mathrm{a}} \pm 0.36$ \\
\hline King chilli toffee & $7.56^{\mathrm{d}} \pm 0.16$ & $1.16^{\mathrm{c}} \pm 0.73$ & $29.76^{\mathrm{d}} \pm 0.57$ \\
\hline King chilli curry paste & & &
\end{tabular}

All values are represented as Mean $\pm \mathrm{SD}$ at $5 \%$ significant level. Mean values with similar superscripts within a column do not differ significantly $(\mathrm{P}<0.05)$. 
Table.3 Antioxidant activity of king chilli and its products

\begin{tabular}{|c|c|c|c|c|c|}
\hline & \multicolumn{5}{|c|}{ PARAMETERS } \\
\hline TREATMENTS & DPPH $^{1}$ & $\mathbf{T F}^{2}$ & $\mathbf{T P}^{3}$ & $\mathbf{R P}^{4}$ & CAROTENOID \\
\hline Fresh King chilli & $15.29^{b} \pm 1.06$ & $12.97^{\mathrm{c}} \pm 0.55$ & $141.28^{\mathrm{d}} \pm 2.65$ & $0.17^{c} \pm 0.00$ & $1.95^{\mathrm{b}} \pm 0.08$ \\
\hline Dry king chilli & $36.86^{\mathrm{a}} \pm 0.47$ & $22.49^{a} \pm 3.89$ & $410.76^{\mathrm{a}} \pm 7.27$ & $0.55^{\mathrm{a}} \pm 0.00$ & $3.99^{\mathrm{a}} \pm 0.64$ \\
\hline $\begin{array}{l}\text { King chili sauce with } \\
\text { pulp }\end{array}$ & $2.84^{\mathrm{d}} \pm 0.32$ & $3.73^{\mathrm{e}} \pm 1.27$ & $11.37^{\mathrm{g}} \pm 0.67$ & $0.07^{\mathrm{e}} \pm 0.00$ & $0.37^{\mathrm{d}} \pm 0.18$ \\
\hline $\begin{array}{l}\text { King chili sauce with } \\
\text { extract }\end{array}$ & $2.80^{\mathrm{d}} \pm 0.36$ & $6.97^{\mathrm{d}} \pm 0.45$ & $20.61^{g} \pm 2.66$ & $0.07^{\mathrm{e}} \pm 0.00$ & $0.13^{\mathrm{d}} \pm 0.04$ \\
\hline Fish Masala powder & $12.67^{\mathrm{b}} \pm 7.16$ & $18.12^{\mathrm{b}} \pm 1.22$ & $213.83^{b} \pm 19.48$ & $0.19^{\mathrm{b}} \pm 0.00$ & $1.05^{\mathrm{c}} \pm 0.15$ \\
\hline $\begin{array}{l}\text { King chilli Sprinkle } \\
\text { masala powder }\end{array}$ & $12.10^{b} \pm 0.19$ & $5.51^{\mathrm{e}} \pm 0.28$ & $184.22^{c} \pm 4.24$ & $0.19^{\mathrm{b}} \pm 0.00$ & $1.43^{\mathrm{c}} \pm 0.14$ \\
\hline King chilli toffee & $6.52^{c} \pm 0.15$ & $9.13^{\mathrm{d}} \pm 0.68$ & $101.50^{\mathrm{e}} \pm 1.12$ & $0.17^{\mathrm{c}} \pm 0.01$ & $0.17^{\mathrm{d}} \pm 0.01$ \\
\hline $\begin{array}{l}\text { King chilli curry } \\
\text { paste }\end{array}$ & $9.37^{\mathrm{c}} \pm 0.75$ & $8.05^{\mathrm{d}} \pm 0.91$ & $80.00^{\mathrm{f}} \pm 5.86$ & $0.10^{\mathrm{d}} \pm 0.01$ & $0.45^{\mathrm{d}} \pm 0.02$ \\
\hline
\end{tabular}

All values are represented as Mean $\pm \mathrm{SD}$ at $5 \%$ significant level. Mean values with similar superscripts within a column do not differ significantly $(\mathrm{P}<0.05)$.

$\mathrm{DPPH}^{1}$ - 1, 1-diphenyl-2-picryl-hydrazil, activity is expressed in \% inhibition

$\mathrm{TF}^{2}$ and $\mathrm{TP}^{3}$-total flavonoid is expressed in $\mathrm{mg} / \mathrm{g}$ rutin equivalent and total phenolics is expressed in $\mathrm{mg} / \mathrm{g}$ as catechol equivalent.

$\mathrm{RP}^{4}$ - Reducing power expressed in absorbance

CAROTENOID expressed in $(\mathrm{mg} / \mathrm{g})$

Table.4 Correlation coefficient of antioxidant activity of King chilli and its products

\begin{tabular}{|l|l|l|l|l|l|}
\hline \multicolumn{2}{|c|}{${ }^{3}$ TF } & CAROTENOIDS & ${ }^{2}$ RP & ${ }^{1}$ DPPH & ${ }^{4}$ TP \\
\hline TF & 1 & & & & \\
\hline CAROTENOIDS & $0.769^{*}$ & 1 & & & \\
\hline RP & $0.814^{*}$ & $0.937^{* * *}$ & 1 & & \\
\hline DPPH & $0.839^{* *}$ & $0.975^{* * *}$ & $0.971^{* * *}$ & 1 & \\
\hline TP & $0.860^{* *}$ & $0.919^{* * *}$ & $0.950^{* * *}$ & $0.956^{* * *}$ & 1 \\
\hline
\end{tabular}

${ }^{1} \mathrm{DPPH}^{-}$1, 1-diphenyl-2-picryl-hydrazil, activity is expressed in \% inhibition.

${ }^{2} \mathrm{RP}$ - Reducing power expressed in $\mathrm{mg} / \mathrm{g}$ fresh weight,

${ }^{3} \mathrm{TF}$ - Total flavonoid is expressed in $\mathrm{mg} / \mathrm{g}$ of rutin equivalent.

${ }^{4} \mathrm{TP}$-total phenolics are expressed in $\mathrm{mg} / \mathrm{g}$ of catechol equivalent.

Carotenoid is expressed in $\mathrm{mg} / \mathrm{g}$.

*- significant $(p>0.05), * *$ - significant $(p>0.01), * * *$-significant $(p>0.005)$

Significant difference $(p>0.05)$ in proline content was observed in all the secondary processed products. Moreover, studies on proline content of Capscicum species have not been reported so far.

Results of antioxidant study in King chilli and its products are presented in Table 3. DPPH scavenging activity was highest $(36.86 \pm 0.47 \%)$ in dry King chilli. The primary processed (dry King chilli) product showed significantly $(\mathrm{p}<0.05)$ higher DPPH scavenging activity as compared to the fresh King chilli and all the secondary processed King chilli products. On the other hand, Rakesh et al., (2014) also observed a low to 
high DPPH scavenging activity in extracts of different coloured peppers ranging from $2.2 \%$ to $52.3 \%$. Total flavonoid content was found to be highest $(22.49 \pm 3.89 \mathrm{mg} / \mathrm{g})$ in dry King chilli. Results of present study in fresh King chilli relates with the total flavonoid content of $12.84 \pm 0.22 \mathrm{mg} / \mathrm{g} \mathrm{RE}$ as reported by Neelam et al., (2015) in red chilli seeds of Capsicum frutescens L. Significant $(p>0.05)$ reduction in total flavonoid content of all the secondary processed products was observed as compared to the dry King chilli. Total phenolic content ranged from $20.61 \pm 2.66$ to $410.76 \pm 7.27 \mathrm{mg} / \mathrm{g}$ of PE). Loizzo et al., (2013) observed that the frying process drastically reduced the total phenolic content in Capsicum annuum fruits, which supports our findings of reduced phenolic content in some secondary processed products.

Dry King chilli had the highest reducing power $(0.55 \pm 0.00$ abs). Dubey et al., (2015) also observed a reducing power activity ranging from 0.92 to $4.10 \mathrm{ASE} / \mathrm{ml}$ in twenty five chilli genotypes from Northeast India which is higher than the findings of our study $(0.17 \pm 0.00$ and $0.55 \pm 0.00$ absorbance in fresh and dry King chilli respectively). The reducing power significantly decreased in all the secondary processed products. Carotenoid content of King chilli and its products ranged from $0.13 \pm 0.04 \mathrm{mg} / \mathrm{g}$ to $3.99 \pm 0.64 \mathrm{mg} / \mathrm{g}$. The carotenoid content in fresh King chilli was found to be $1.95 \pm 0.08 \mathrm{mg} / \mathrm{g}$ whereas it was $3.99 \pm 0.64 \mathrm{mg} / \mathrm{g}$ in dry King chilli. Similar findings of $2.5 \pm 0.8 \mathrm{mg} / \mathrm{g}$ and $4.0 \pm 0.8 \mathrm{mg} / \mathrm{g}$ of carotenoid were reported by Loizzo et al., (2013) in two bell Capsicum annuum L. cultivars. Statistical analysis revealed that the total phenolic content in different King chilli products strongly correlated $(\mathrm{p}>0.005)$ with scavenging DPPH $(\mathrm{r}=0.95)$, reducing power $(\mathrm{r}=0.95)$ and total flavonoid content $(\mathrm{r}=0.86)$ as given in Table 4. Phenolics present in King chilli scavenge reactive oxygen species due to their electron donating properties. Their antioxidant effectiveness depends on the stability in different systems, as well as number and location of hydroxyl groups. Phenolic compounds acting as antioxidants may function as terminators of free radical chains and as chelators of redox-active metal ions that are capable of catalyzing lipid peroxidation (Aminah and Anna, 2011). The results indicate that King chilli and its products are good sources of phenolic compounds which can become potential sources of bio active compounds and the value added products can serve as functional foods.

From the present study, it was observed that King chilli and its products are fairly good sources of many nutrient and antioxidant properties like capsaicin, ascorbate, fat, fibre, protein, flavonoids, phenolics, carotenoids and DPPH activities. In view of its potential use and applications in food preparations, we can conclude that value added King chilli products can serve as an alternative source of functional and bioactive components in the near future.

\section{Acknowledgements}

The authors thank DBT's Twinning programme for NER, ICAR-NER, Imphal, Manipur and PJTSAU, Rajendranagar, Hyderabad for providing all the facilities to perform the study.

\section{References}

1. Baruah S, Zaman MK, Rajbongshi $\mathrm{P}$ and Das S, A Review on Recent Researches on Bhut jolokia and Pharmacological Activity of Capsaicin. International Journal of Pharmacological Sciences, 2014, 24(2), 8994.

2. Sarwa KK, Kira J, Sahu,J, Rudrapal M and Debnath M, A short review on Capsicum 
chinense Jacq. Journal of Herbal Medicine and Toxicology, 2012, 6, 7-10.

3. Raktim RB and Changkija S, Genetic variability and traditional practices in naga king chili landraces of Nagaland. Asian Agri-History, 2009, 13, 171-180.

4. Hoffman PG, Lego MC and Galetto WG, Separation and quantitation of red pepper major heat principles by reverse-phase high pressure liquid chromatography. Journal of Agricultural and Food Chemistry, 1983, 31, 1326-1330.

5.Prasad NBC, Shrivastava R and Ravishankar GA, Capsaicin: a promising multifaceted drug from Capsicum spp. Evidence-Based Integrative Medicine, 2005, 2, 147-166.

6. Mori A, Lehmann S, O'Kelly J, Kumagai $\mathrm{T}$, Desmond JC, et al., Capsaicin, a component of red peppers, inhibits the growth of androgen-independent, p53 mutant prostate cancer cells. Cancer Research, 2006, 66, 3222-3229.

7. Shobana S and Naidu KA, Antioxidant activity of selected Indian spices. Prostaglandins, Leukotrienes and Essential Fatty Acids, 2000, 62, 107-110.

8. Yu R, Choi M, Kawada T, Kim B, Han S and Yoo $\mathrm{H}$, Inhibitory effect of capsaicin against carcinogen-induced oxidative damage in rats. Journal of Food Science and Nutrition, 2002, 7, 67-71.

9. AOAC. 2000. Official methods of analysis. Association of Analytical chemists. Washington, D.C. $17^{\text {th }}$ edition.

10. Mukherjee SP and Choudhuri MA, Implications of water stress induced changes in the level of endogenous ascorbic acid and hydrogen peroxide in Vigna seedlings. Physiologia plantarum, 1983, 58, 166-170.

11. Quagliotti L, Effects of soil moisture and nitrogen level on the pungency of berries of Capsicum annum L, Horticulture Research. 1971, 11, 93-97.
12. Bates L, Waldren RP and Teare ID, Rapid determination of free proline for waterstress studies. Plant and Soil, 1973,39, 205207.

13. Blois MS, Antioxidant determinations by the use of a stable free radical. Nature,1985, 26,1199-1200.

14. Ordonez AAL, Gomez JD, Vattuone MA and Isla MI, Antioxidant activities of Sechium edule (Jacq). Food Chemistry, 2006, 97, 452-458.

15. Lowry $\mathrm{OH}$, Protein measurement with the Folin-phenol reagent. Journal of Biological Chemistry, 1951, 193, 265-275.

16. Oyaizu M, Studies on products of browning reaction prepared from glucosamine. Japan Journal of Nutrition, 1986, 44, 307-314.

17. Jensen A, Chlorophylls and carotenoids. Handbook of phycological methods, physiological and biochemical methods. Cambridge University Press, Cambridge, 1978, 59-70.

18. Snedecor GM and Cochran WC, Statistical Methods. 6th Edition, Iowa University Press, 1969, Ames, Iowa.

19. Ananthan R, Subash K and Longvah T, Assessment of nutrient composition and capsaicinoid content of some red chillies. International conference on food and nutrition technology, IACSIT Press Singapore. IPCBEE, 2014, 72: 1-4.

20. Sanatombi K and Sharma GJ, Capsaicin content and pungency of different Capsicum spp. cultivars. Notulae Botanicae Horti Agrobotanici Cluj-Napoca, 2008, 36, 89-90.

21. Take AM, Jadhav SL and Bhotmange MG, Effect of Pretreatments on Quality Attributes of Dried Green Chilli Powder. ISCA Journal of Engineering Sciences, 2012, 1(1), 71-74.

22. Ji-Sun K, Jiyun A, Sung-Joon L, Bokyung $\mathrm{M}$, Tae-Youl $\mathrm{H}$ and et al., Phytochemicals and antioxidant activity of fruits and leaves of paprika (Capsicum annuum L., var. special) cultivated in Korea. Journal of 
Food Science,2011, 76, C193-C198.

23. Ananthan R, Subash K, Mangthya K and Longvah T, Capsaicinoid, amino acid and fatty acid profiles in fruit components of Naga King chilli (Capsicum chinense Jacq.) and Guntur red chilli (Capsicum annuum L.). Proceedings of the International food database conference, National Institute of Nutrition (ICMR), Hyderabad, 2015.

24. Jana S, Vesna R, Zoran K and Marija S, Nutritive and bioactive compounds in hot fruits of Capsicum annuum L. from Macedonia. Macedonian Journal of Chemistry and Chemical Engineering, 2014, 33(1).

25. Rakesh S and Joshi VK, Development and evaluation of bell pepper (Capsicum annuиm L.) based instant chutney powder. Indian Journal of Natural Products and Resources, 2014, 5(3), 262-267.

26. Neelam G, Madhu G, Darshana M and Bhupendra KM, Chemical composition, total phenolic and flavonoid contents, and in vitro antimicrobial and antioxidant activities of crude extracts from red chilli seeds (Capsicum frutescens L.), Journal of Taibah University for Science, 2015, http://dx.doi.org/10.1016/j.jtusci.2015.06.0 11.

27. Loizzo MR, Pugliese A, Bonesi M, Luca DD, O'Brien N, Menichini $\mathrm{F}$ and Tundis $\mathrm{R}$, Influence of drying and cooking process on the phytochemical content, antioxidant and hypoglycaemic properties of two bell Capsicum annum L. cultivars. Food and Chemical Toxicolog, 2013, 53, 392-401.

28. Dubey RK, Singh V, Upadhyay G, Pandey AK and Dhan P, Assessment of phytochemical composition and antioxidant potential in some indigenous chilli genotypes from North East India. Food Chemistry, 2015, 188, 119-125.

29. Aminah A, Anna PK (2011) Influence of ripening stages on physico-chemical characteristics and antioxidant properties of bitter gourd (Momordica charantia). International food research. 18: 895-900.

\section{How to cite this article:}

Aparna Kuna, Manas Ranjan Sahoo, M. Sowmya, Premi Devi Mayengbam, M.Dasgupta, M. Sreedhar and Shinglai Tholemfhuang. 2018. Nutrient and Antioxidant Properties of Value Added King Chilli (Capsicum chinense) Products. Int.J.Curr.Microbiol.App.Sci. 7(06): 1-8. doi: https://doi.org/10.20546/ijcmas.2018.706.001 